\title{
Motivasi Tenaga Kerja RSD Mangusada Badung-Bali dalam Mempelajari Bahasa Inggris
}

\author{
Category of Motivation in Learning English of RSD Mangusada Staffs
}

\author{
Ketut Santi Indriani \\ Program Studi Sastra Inggris, Fakultas Ilmu Budaya \\ Universitas Udayana \\ Email correspondence: kt.santi.indriani@unud.ac.id
}

Received: 20 Oktober 2020 Revised: 2 Februari 2021 Accepted: 3 Februari 2021

\begin{abstract}
This study aims to identify the categories of motivation and appropriate stimulants for the RSD Mangusada staffs in learning English. This research is a qualitative research with method of collecting data using questionnaire distributed to 50 staff of RSD Mangusada from various divisions. The questionnaire contains closed questions that are filled out using Likert's scale. The data in this study were analyzed descriptive-qualitatively by describing the categories of motivation in learning English. The results of the data analysis show that there are five categories of single dominant motivation and three categories of combined dominant motivation possessed by the staff of Mangusada Badung Hospital in learning English, those are intrinsic dominant motivation category, extrinsic dominant, integrative dominant, instrumental dominant, amotivation dominant, intrinsic- integrative dominant, intrinsic-instrumental dominant and extrinsic-instrumental dominant. Based on the results of the data analysis, it can be concluded that the main factor which encourages Mangusada Hospital staffs to learn English is only limited to the desire to fulfill practical needs, such as the desire to get a better job and/or to get a higher income. The desire to fulfill this practical need arises both from within the learners and from the environment. Thus, if RSD Mangusada needs to improve the English competence of all its staff in order to improve services, pragmatic stimulants is needed in order to get an optimal result.
\end{abstract}

Keywords: language learning, ESL, learning motivation

\begin{abstract}
Abstrak: Penelitian ini bertujuan untuk mengidentifikasi kategori motivasi dan stimulan yang tepat untuk tenaga kerja RSD Mangusada dalam mempelajari bahasa Inggris. Penelitian ini merupakan penelitian kualitatif dengan metode pengumpulan data menggunakan kuesioner yang dibagikan kepada 50 staf RSD Mangusada dari berbagai divisi. Kuesioner berisi pertanyaan tertutup yang diisi menggunakan skala Likert. Data dalam penelitian ini dianalisis secara deskriptif kualitatif dengan menjabarkan kategori motivasi tenaga kerja RSD Mangusada dalam mempelajari bahasa Inggris. Hasil analisis data menunjukkan bahwa ada lima kategori motivasi tunggal dominan dan tiga kategori motivasi gabungan dominan yang dimiliki oleh staf Rumah Sakit Mangusada Badung dalam mempelajari bahasa Inggris, yaitu kategori motivasi intrinsik dominan, ekstrinsik dominan, integratif dominan, instrumental dominan, amotivasi dominan, intrinsik-integratif dominan, intrinsik-instrumental dominan, dan ekstrinsik-instrumental dominan. Berdasarkan hasil analisis data tersebut, dapat disimpulkan bahwa hal utama yang mendorong tenaga kerja RSUD Mangusada dalam memelajari bahasa Inggris hanya terbatas pada keinginan untuk mendapatkan memenuhi kebutuhan praktis, seperti keinginan untuk mendapatkan pekerjaan yang lebih baik dan/atau untuk memperoleh pendapatan yang lebih besar. Keinginan pemenuhan kebutuhan praktis ini muncul baik dari dalam diri sendiri, maupun dorongan dari luar. Dengan demikian, apabila RSD Mangusada ingin meningkatkan kompetensi berbahasa Inggris seluruh stafnya guna peningkatan pelayanan, maka diperlukan stimulan yang bersifat pragmatis sehingga hasil yang diperoleh menjadi optimal. Kata kunci: pembelajaran bahasa, bahasa Inggris, motivasi belajar
\end{abstract}

To cite this article:

Indriani, K. S. (2021). Motivasi Tenaga Kerja RSD Mangusada Badung-Bali dalam Mempelajari Bahasa Inggris. Diglosia: Jurnal Kajian Bahasa, Sastra, dan Pengajarannya, 4(1), 115-126. https://doi.org/10.30872/diglosia.v4i1.130 


\section{A. PENDAHULUAN}

Motivasi meegang peranan yang penting dalam pembelajaran bahasa. Setiap tenaga pengajar harus mengenali karakter dan jenis motivasi yang dimiliki oleh setiap peserta didiknya (Mahadi \& Jafari, 2012). Ketika seorang tenaga pengajar mempersiapkan kegiatan pembelajaran, maka analisis motivasi yang dimiliki oleh peserta didiknya harus menjadi bahan pertimbangan. Keberhasilan seseorang dalam proses pembelajaran bahasa sangat dipengaruhi oleh motivasi yang dimilikinya. Motivasi seseorang juga berkaitan erat dengan strategi belajar yang dipilih oleh orang tersebut (Rashid \& Akram, 2019).

Rumah Sakit Daerah (RSD) Mangusada Badung merupakan salah satu pusat pelayanan kesehatan pemerintah yang berada di Kabupaten Badung. RSD Mangusada Badung memiliki frekuensi yang cukup tinggi dalam melayani kesehatan bagi wisatawan asing. Kemampuan berbahasa Inggris tidak hanya dibutuhkan oleh tenaga medis yang berhubungan langsung dengan pasien asing tetapi juga dibutuhkan oleh tenaga kerja rumah sakit yang lain. Kemampuan berbahasa Inggris yang dimiliki oleh setiap tenaga kerja di lingkungan RSD Mangusada Badung tentunya tidaklah sama. Hal ini akan sangat dipengaruhi motivasi mereka dalam mempelajari bahasa Inggris. Horwitz (2002) menyatakan bahwa motivasi adalah sebuah keadaan kognitif dan emosional yang muncul pada diri seseorang dan mengarah pada pengambilan keputusan secara sadar untuk bertindak dan memberi upaya fisik dan intelektual secara berkelanjutan. Penelitian ini bertujuan untuk mengidentifikasi kategori motivasi yang dimiliki oleh tenaga kerja RSD Mangusada Badung dalam mempelajari bahasa Inggris. Hal ini berkaitan dengan usaha manajemen RSD Mangusada Badung untuk meningkatkan kompetensi berbahasa Inggris bagi seluruh staf dalam upaya peningkatan pelayanan bagi pasien.

Motivasi adalah sebuah perasaan seseorang yang diaktifkan menuju sebuah akhir. Dengan demikian, dimotivasi berarti digerakkan untuk melakukan sesuatu (Ryan \& Deci, 2000). Hal yang serupa juga disampaikan oleh Johnstone (1999). Menurutnya, motivasi adalah sebuah stimulan untuk mencapai suatu target tertentu. Motivasi juga dapat didefinisikan sebagai sebuah proses internal yang tidak dapat diobservasi secara langsung tetapi dapat mengaktivasi, menuntun, dan menjaga keberlangungan sebiuah kebiasaan yang dapat dilihat dengan jelas (Baron, 1996). Dengan demikian, dapat disimpulkan bahwa motivasi adalah sebuah dorongan atau stimulan yang tidak dapat diamati secara langsung namun menggerakkan dan menuntun seseorang untuk melakukan sesuatu guna mencapai sebuah target tertentu. Motivasi siswa bukan merupakan sebuah faktor pendukung dalam keberhasilan proses pembelajaran namun justru menjadi faktor utama dalam sebuah kegiatan pembelajaran. Memacu motivasi siswa dapat meningkatkan efek keberhasilan proses belajar dan mengajar yang akan berdampak pada meningkatnya kemampuan praktis berbahasa Inggris siswa (Long, Ming, \& Chen, 2013).

Motivasi dapat dibagi menjadi beberapa kategori. Ryan \& Deci (2000) membagi motivasi menjadi dua kategori, yaitu intrinsik dan ekstrinsik. Sementara itu, (Gardner, 1985) membagi motivasi menjadi dua kategori lain, yaitu integrative dan instrumental. Satu kategori motivasi yang lain dikemukakan oleh Pakdel (2013). Kelima kategori motivasi tersebut adalah (a) motivasi intrinsik adalah sebuah dorongan yang berasal dari dalam diri seseorang dan bekerja dari dalam diri orang tersebut; (b) motivasi ekstrinsik atau motivasi buatan mengacu pada penyemangat yang berasal dari lingkungan, seperti uang, makanan, pengakuan, dan sebagainya 
yang menuntun perilaku untuk mencapai sebuah tujuan; (c) motivasi integratif adalah motivasi yang berkaitan dengan budaya bahasa yang dipelajari; (d) motivasi instrumental berkaitan dengan kebutuhan praktis seseorang, seperti kebutuhan untuk memperoleh pekerjaan, kebutuhan untuk lulus dalam ujian, atau kebutuhan untuk mendapatkan income yang lebih besar; dan (e) amotivasi berarti seseorang tidak memiliki motivasi dalam melakukan sesuatu.

Motivasi intrinsik adalah motivasi yang berasal dari dalam diri seseorang yang mendorong orang tersebut untuk berfikir, melakukan tindakan, maupun mempertahankan prilaku terhadap sesuatu. Dalam kaitannya dengan proses mempelajarai bahasa Inggris, maka motivasi intrinsik adalah motivasi yang timbul dari dalam diri siswa untuk mempelajari bahasa Inggris. Aydoğan (2016) menyatakan bahwa seseorang yang secara intrinsik termotivasi dalam mempelajari bahasa Inggris akan dengan sendirinya mempunyai ketertarikan untuk mempelajari bahasa tersebut. Indikator seseorang memiliki motivasi intrinsik adalah apabila orang tersebut mendapatkan kesenangan dari aktivitas terntentu, melakukan sesuatu tanpa menikirkan pengakuan dari orang lain, dan menujukkan minat yang tulus dalam bidang tertentu.

Menurut Shaikholeslami \& Khayyer (2006), siswa yang memiliki motivasi intrinsik akan cenderung untuk mempercayai atau berfikir bahwa pembelajaran itu penting. Hal ini menunjukkan bahwa kesadaran akan apa yang dipelajari adalah penting berasal dari diri sendiri. Hal ini akan mendeorongnya untuk giat mempelajari bahasa Inggris sebab ia mempercayai bahawa bahasa Inggris proses pembelajaran itu penting.

Beberapa peneliti meyakini bahwa motivasi intrinsik dalam mempelajari bahasa Inggris adalah motivasi yang tidak ada imbalannya kecuali aktivitas belajar itu sendiri yang dapat memberikan manfaat secara internal, seperti kemampuan dan kompetensi berbahasa Inggris. Siswa yang memiliki motivasi intrinsik dapat dilihat pada situasi ketika semua siswa dalam satu kelas sangat bersemangat mempelajari bahasa Inggris pada pertemuan-pertemuan awal. Kan tetapi, pada pertemuanpertemuan selanjutnya hanya siswa yang memiliki motivasi intrinsik yang akan tetap bersemangat dalam mempelajari bahasa Inggris ketika semangat teman-teman yang lain sudah mulai menurun.

Motivasi ekstrinsik memiliki sifat yang berlawanan dengan motivasi intrinsik. Dorongan untuk melakukan sesuat pada seseorang yang memiliki motivasi ekstrinsik berasal dari luar diri orang tersebut. Berkaitan dengan proses mempelajari bahasa Inggris, maka siswa yang memiliki motivasi ekstrinsik mempelajari bahasa Inggris karena ada dorongan dari luar dirinya. Aydoğan (2016) menyatakan bahwa seseorang yang termotivasi secara ekstrinsik akan melakukan sesuatu untuk mendapatkan nilai yang bai, mendapat pujian, dan dianggap paling pintar. Dengan demikian, ciri-ciri seseorang yang memiliki motivasi ekstrinsik adalah jika ia melakukan sesuatu untuk mendapatkan penghargaan, sangat berorientasi pada hasil, atau ingin mendapatkan pujian dari orang lain (misalnya ingin orang lain melihat bahwa dia adalah siswa terbaik, paling menonjol, atau paling pintar). Seseorang yang memiliki motivasi ekstrinsik cenderung menganggap bahwa dirinya tidak memiliki kemampuan dan tidak dapat mengambil sebuah keputusan. Tindakan mereka seringkali dikendalikan oleh orang lain. Seorang siswa dengan motivasi ekstrinsik akan selalu memikirkan pendapat guru jika tugas yang mereka kerjakan tidak memuaskan (Kamaruddin, Sha'ri, Ghazali, \& Hamdan, 2017). 
Seorang siswa yang memiliki motivasi integratif dalam mempelajari bahasa berarti siswa tersebut mempunyai keinginan untuk mempelajari bahasa agar ia dapat berkomunikasi dengan penuh percaya diri dengan komunitas penutur bahasa tersebut (Al-Ta'ani, 2018). Delgado (2016) menambahkan, jika seorang siswa memiliki motivasi integratif, ia akan selalu terinspirasi untuk belajar. Ia juga akan sangat menikmati percakapan dalam sebuah kelompok bahasa, serta selalu memiliki sikap positif terhadap pembelajaran bahasa.

Al-Ta'ani (2018) menyatakan bahwa motivasi instrumental dalam mempelajari bahasa adalah minat siswa dalam mempelajari bahasa dengan tujuan untuk meningkatkan kualifikasi diri dan meningkatkan prospek karir. Seseorang yang mempelajari sebuah bahasa dengan motivasi instrumental cenderung untuk mempelajari bahasa tersebut demi kepentingan pragmatis, seperti mendapatkan pekerjaan atau mendapatkan lebih banyak uang. Dengan kata lain, ia cenderung mempelajari suatu bahasa untuk mendapatkan gaji yang lebih baik, mendapatkan bonus, masuk kuliah, atau mendapatkan promosi. Kondisi ini menggambarkan bahwa siswa cenderung untuk mengharapkan imbalan sebagai penghargaan terhadap prestasi mereka dalam mempelajari suatu bahasa. Mereka meyakini bahwa pengorbanan mereka dalam mempelajari suatu bahasa akan dihargai dengan imbalan berupa uang atau promosi jabatan (Delgado, 2016).

Tidak semua siswa memiliki dorongan untuk mempelajari sebuah bahasa, khususnya bahasa Inggris. Beberpa siswa kadang kala tidak memilki dorongan atau keinginan untuk mempelajari bahasa Inggris. Baik dorongan dari dalam dirinya sendiri ataupun dorongan dari luar tidak ia miliki sehingga ia tidak termotivasi dalam mempelajari bahasa Inggris. Dengan demikian, siswa tersebut dikatakan tidak termotivasi atau amotivasi.

\section{B. METODE}

Penelitian ini merupakan penelitian kualitatif yang dilakukan di Rumah Sakit Umum Daerah Mangusada Badung yang terletak Jalan Raya Kapal, Mangupura, Mengwi, Kabupaten Badung, Bali. Sumber data penelitian ini digambarkan dengan populasi dan sampel sebagai berikut. Populasi pada penelitian ini adalah tenaga kerja RSD Mangusada Badung dengan sampel lima puluh orang tenaga kerja RSD Mangusada Badung yang berasal dari berbagai divisi, yakni tenaga kesehatan (dokter umum, perawat, dan petugas laboratorium) serta tenaga nonkesehatan (bagian pendaftaran, kasir, operator telepon dan layanan pelanggan). Pemilihan sampel dilakukan dengan metode sampel acak sederhana.

Data pada penelitian ini dikumpulkan dengan menggunakan kuesioner yang terdiri atas 25 pertanyaan tertutup berkaitan dengan motivasi belajar bahasa Inggris tenaga kerja RSD Mangusada Badung. Responden diminta untuk memilih jawaban dari pertanyaan-pertanyaan pada kuesioner dengan memilih skor 1 sampai dengan 5 menggunakan penilaian skala Likert.

Perhitungan setiap kategori motivasi yang dimiliki oleh setiap responden dilakukan dengan merata-ratakan skor yang diberikan pada setiap pertanyaan berkaitan dengan masing-masing kategori motivasi. Setelah itu, dilakukan perhitungan pada setiap kelompok pertanyaan berdasarkan kategori motivasi yang telah dirata-ratakan untuk menemukan kategori motivasi manakah yang tergolong bernilai rata-rata tinggi. Hasil rata-rata setiap kategori motivasi diinterpretasikan sebagai berikut. 
Tabel 1. Interpretasi Rentangan Nilai Rata-Rata setiap Kategori Motivasi

\begin{tabular}{cll}
\hline No & Rentangan Nilai Rata-Rata & Deskripsi \\
\hline 1. & $3,61-5,00$ & Motivasi tinggi \\
2. & $2,21-3,60$ & Motivasi sedang \\
3. & $1,00-2,20$ & Motivasi rendah \\
\hline
\end{tabular}

\section{PEMBAHASAN}

1. Kategori Motivasi Tenaga Kerja RSD Mangusada Badung dalam Mempelajari Bahasa Inggris

Motivasi merupakan bagian terpenting dalam mempelajari suatu bahasa, khususnya bahasa Inggris. Motivasi siswa dalam mempelajari suatu bahasa akan menentukan sikap siswa terhadap bahasa dan selama proses pembelajaran. Motivasi yang dimiliki siswa dapat beragam, diantaranya motivasi intrinsik, ekstrinsik, integratif, dan instrumental. Namun, siswa juga dapat tidak memiliki motivasi dalam mempelajari bahasa Inggris.

Berdasarkan hasil analysis data, ditemukan bahwa terdapat bernagai macam motivasi yang dimiliki oleh tenaga kerja RSD Mangusada Badung dalam mempelajari bahasa Inggris, yaitu motivasi intrinsik dominan, ekstrinsik dominan, integratif dominan, instrumental dominan, amotivasi, intrinsik-integratif, dan intrinsik-instrumental.

Tabel 2 menunjukkan kategori motivasi belajar bahasa Inggris staf RSD Mangusada Badung. Data menunujukkan bahwa responden dapat memiliki lebih dari satu kategori motivasi dalam mempelajari bahasa Inggris. Dari 50 responden pada penelitian ini, ditemukan 3 orang responden memiliki motivasi intrinsik, 5 orang memiliki motivasi ekstrinsik, 2 orang memiliki motivasi integratif, 1 orang memiliki motivasi instrumental, dan 2 orang tidak memiliki motivasi (amotivasi) dalam mempelajari bahasa Inggris. Selain itu, terdapat sekelompok responden yang memiliki lebih dari satu kategori motivasi dalam mempelajari bahasa Inggris, yaitu 5 orang memiliki motivasi intrinsic-integratif, 24 orang memiliki motivasi intrinsicinstrumental, serta 8 orang memiliki motivasi ekstrinsik dan instrumental.

Tabel 2. Kategori Motivasi Tenaga Kerja RSD Mangusada Badung dalam Mempelajari Bahasa Inggris

\begin{tabular}{clc}
\hline No & Kategori Motivasi & Jumlah (orang) \\
\hline 1. & Motivasi intrinsik & 3 \\
2. & Motivasi ekstrinsik & 5 \\
3. & Motivasi integratif & 2 \\
4. & Motivasi instrumental & 1 \\
5. & Amotivasi & 2 \\
6. & Motivasi intrinsik-integratif & 5 \\
7. & Motivasi intrinsic-instrumental & 24 \\
8. & Motivasi ekstrinsik-instrumental & 8 \\
\hline & Total & $\mathbf{5 0}$ \\
\hline
\end{tabular}




\section{a. Kategori Motivasi Intrinsik}

Motivasi intrinsik adalah motivasi atau dorongan yang berasal dari diri seseorang yang bekerja pada diri orang itu sendiri (Ryan \& Deci, 2000). Dalam mempelajari bahasa Inggris motivasi intrinsik akan mendorong seseorang untuk mengupayakan berbagai macam cara agar dapat mencapai tujuan pembelajaran. Motivasi intrinsik muncul karena tujuan utama dalam mempelajari bahasa Inggris adalah untuk memahami bahasa tersebut. Persentase motivasi intrinsik yang muncul pada data sangatlah kecil, yakni hanya $6 \%$ atau sebanyak 3 orang responden. Rentangan nilai rata-rata kategori motivasi intrinsik yang diperoleh pada ketiga orang responden tersebut adalah 4,20-4,40. Sementara itu, keempat kategori motivasi yang lain memiliki rentangan nilai rata-rata rendah, yaitu kategori motivasi ekstrinsik dengan rentangan nilai rata-rata 1,60-1,80; kategori motivasi integratif dengan rentangan nilai rata-rata $1,80-2,20$; kategori motivasi instrumental dengan rentangan nilai rata-rata $1,20-1,60$; dan kategori amotivasi dengan rentangan nilai rata-rata $1,00-1,20$.

Perbandingan nilai rata-rata setiap kategori motivasi pada ketiga orang responden tersebut dapat dilihat pada diagram 1, yaitu kategori motivasi intrinsik memiliki rata-rata 4,33; kategori motivasi ekstrinsik memiliki rata-rata 1,73; kategori motivasi integratif memiliki rata-rata 2,00; kategori motivasi instrumental memiliki rata-rata 1,47; dan kategori amotivasi memiliki rata-rata 1,07.

\section{b. Kategori Motivasi Ekstrinsik}

Motivasi ekstrinsik adalah motivasi yang berasal dari dorongan dari luar diri seseorang. Dalam mempelajari bahasa Inggris, motivasi berasal dari hal-hal di luar peserta belajar, seperti orang tua, lingkungan, atau faktor-faktor lain yang berasal dari luar. Pada Tabel 2 ditunjukkan bahwa motivasi ekstrinsik ditemukan pada 5 orang responden atau sebesar $10 \%$ dari seluruh jumlah responden pada penelitian ini. Rentangan nilai rata-rata kategori motivasi ekstrinsik yang diperoleh pada kelima orang responden tersebut adalah 4,20-4,80. Sementara itu, keempat kategori motivasi yang lain memiliki rentangan nilai rata-rata sedang hingga rendah, yaitu kategori motivasi intrinsik dengan rentangan nilai rata-rata $1,20-1,40$; kategori motivasi integratif dengan rentangan nilai rata-rata $1,60-1,80$; kategori motivasi instrumental dengan rentangan nilai rata-rata $2,40-2,60$; dan kategori amotivasi dengan rentangan nilai rata-rata $1,00-1,40$.

Perbandingan nilai rata-rata setiap kategori motivasi pada kelima orang responden tersebut dapat dilihat pada diagram 2, yaitu kategori motivasi intrinsik memiliki ratarata 1,28; kategori motivasi ekstrinsik memiliki rata-rata 4,52; kategori motivasi integratif memiliki rata-rata 1,68 ; kategori motivasi instrumental memiliki rata-rata 2,44; dan kategori amotivasi memiliki rata-rata 1,12. Dengan demikian dapat dinyatakan bahwa kategori motivasi kelima responden tersebut dalam mempelajari bahasa Inggris yang dominan adalah motivasi ekstrinsik.

\section{c. Kategori Motivasi Integratif}

Motivasi integratif adalah motivasi sesorang untuk mempelajari bahasa karena tertarik dengan budaya pengguna bahasa tersebut. Motivasi integratif cenderung muncul karena seseorang ingin mengenal lebih baik lagi suatu budaya sehingga membutuhkan penguasaan bahasa dalam mempelajari lebih dalam budaya tersebut. Pada penelitian ini, responden yang memiliki kategori motivasi integratif dalam 
mempelajari bahasa Inggris adalah sebanyak 2 orang atau hanya $4 \%$ dari seluruh jumlah responden pada penelitian ini. Nilai rata-rata kategori motivasi integratif yang diperoleh pada kedua orang responden tersebut adalah 4,80. Sementara itu, keempat kategori motivasi yang lain memiliki nilai rata-rata sedang hingga rendah, yaitu kategori motivasi intrinsik dengan nilai rata-rata 2,60 dan 3,00; kategori motivasi ekstrinsik dengan nilai rata-rata 1,80 dan 2,20; kategori motivasi instrumental dengan rentangan nilai rata-rata 1,40-2,00; dan kategori amotivasi dengan nilai rata-rata 1,00.

Perbandingan nilai rata-rata setiap kategori motivasi pada kedua orang responden tersebut dapat dilihat pada diagram 3, yaitu kategori motivasi intrinsik memiliki rata-rata 2,80; kategori motivasi ekstrinsik memiliki rata-rata 2,00; kategori motivasi integratif memiliki rata-rata 4,80; kategori motivasi instrumental memiliki rata-rata 1,70; dan kategori amotivasi memiliki rata-rata 1,00. Dengan demikian dapat dinyatakan bahwa kategori motivasi kedua responden tersebut dalam mempelajari bahasa Inggris yang dominan adalah motivasi integratif.

\section{d. Kategori Motivasi Instrumental}

Dalam hal mempelajari bahasa Inggris, responden yang memiliki ketegori motivasi instrumental mempelajari bahasa Inggris karena dorongan untuk memenuhi kebutuhan-kebutuhan praktis seperti yang telah disebutkan di atas. Hanya ditemukan 1 orang responden atau sebesar $2 \%$ dari seluruh jumlah responden yang memiliki kategori motivasi instrumental. Nilai rata-rata kategori motivasi instrumental yang diperoleh pada responden tersebut adalah 4,80. Sementara itu, keempat kategori motivasi yang lain memiliki nilai rata-rata sedang dan rendah, yaitu kategori motivasi intrinsik dengan nilai rata-rata 2,00; kategori motivasi ekstrinsik dengan nilai rata-rata 3,40; kategori motivasi integratif dengan rentangan nilai rata-rata 1,40; dan kategori amotivasi dengan nilai rata-rata 1,00.

Nilai rata-rata setiap kategori motivasi pada responden tersebut dapat dilihat pada diagram 4. Dengan demikian dapat dinyatakan bahwa kategori motivasi yang dimiliki oleh responden tersebut dalam mempelajari bahasa Inggris yang dominan adalah motivasi instrumental.

\section{e. Kategori Amotivasi}

Amotivasi berarti tidak adanya motivasi. Dengan demikian dapat dikatakan bahwa 2 orang responden atau 4\% dari seluruh jumlah responden tidak memiliki motivasi dalam mempelajari bahasa Inggris. Tidak ada faktor, baik dari dalam maupun dari luar diri kedua orang responden tersebut yang mendorong mereka untuk mempelajari bahasa Inggris. Nilai rata-rata kategori amotivasi yang diperoleh pada kedua orang responden tersebut adalah 3,80 dan 4,00. Sementara itu, keempat kategori motivasi yang lain memiliki nilai rata-rata rendah, yaitu kategori motivasi intrinsik dengan nilai rata-rata 1,60 dan 2,00; kategori motivasi ekstrinsik dengan nilai rata-rata 1,00 dan 1,40; kategori motivasi integratif dengan rentangan nilai ratarata 1,40-1,60; dan kategori instrumental dengan nilai rata-rata 1,60 dan 2,00.

Perbandingan rentangan nilai rata-rata setiap kategori motivasi pada kedua orang responden tersebut dapat dilihat pada diagram 5, yaitu yaitu kategori motivasi intrinsik memiliki rata-rata 1,80; kategori motivasi ekstrinsik memiliki rata-rata 1,20; kategori motivasi integratif memiliki rata-rata 1,70; kategori motivasi instrumental memiliki rata-rata 1,80; dan kategori amotivasi memiliki rata-rata 3,90. Dengan 
demikian dapat dinyatakan bahwa kategori motivasi kedua responden tersebut dalam mempelajari bahasa Inggris yang dominan adalah amotivasi.

\section{f. Kategori Motivasi Intrinsik-Integratif}

Selain kelima kategori di atas, ditemukan kombinasi gabungan dari dua kategori motivasi yang dimiliki oleh responden dalam mempelajari bahasa Inggris. Gabungan dua kategori motivasi tersebut adalah kategori motivasi intrinsik dan integratif, kategori motivasi intrinsik dan instrumental, serta kategori motivasi ekstrinsik dan instrumental.

Gabungan dua kategori pertama yang ditemukan adalah kategori motivasi instrinsik dan integratif. Dalam kaitannya dengan mempelajari bahasa Inggris, gabungan kedua motivasi ini menunjukkan bahwa seseorang mempelajari bahasa Inggris karena dorongan yang berasal dari dalam dirinya dan disertai dengan keinganan orang tersebut untuk mengenal dan mempelajari budaya dari pengguna bahasa tersebut. Jumlah responden yang memiliki gabungan kategori motivasi intrinsik dan integratif yang ditemukan pada penelitian ini adalah sebanyak 5 orang atau sebesar $10 \%$ dari seluruh jumlah responden. Rentangan nilai rata-rata kedua kategori motivasi tersebut terinterpretasikan tinggi, yaitu kategori motivasi intrinsik dengan rentangan nilai rata-rata 4,80-5,00 dan kategori motivasi integratif dengan rentangan nilai 3,80-4,60. Dari perhitungan nilai rata-rata kedua kategori motivasi tersebut diketahui kategori motivasi intrinsik lebih tinggi muncul dalam diri kelima responden tersebut. Sementara itu, ketiga kategori motivasi yang lain memiliki nilai rata-rata sedang dan rendah, yaitu kategori motivasi ekstrinsik dengan rentangan nilai rata-rata $1,00-1,40$; kategori motivasi instrumental dengan rentangan nilai rata-rata 2,40 dan 3,00; dan kategori amotivasi dengan rentangan nilai rata-rata $1,00-1,20$.

Perbandingan rentangan nilai rata-rata setiap kategori motivasi pada kelima orang responden tersebut dapat dilihat pada $\mathrm{d} 6$, yaitu yaitu kategori motivasi intrinsik memiliki rata-rata 4,96; kategori motivasi ekstrinsik memiliki rata-rata 1,12 ; kategori motivasi integratif memiliki rata-rata 4,28; kategori motivasi instrumental memiliki rata-rata 2,52; dan kategori amotivasi memiliki rata-rata 1,04. Dengan demikian dapat dinyatakan bahwa kategori motivasi yang dimiliki oleh kelima responden tersebut dalam mempelajari bahasa Inggris yang dominan adalah motivasi intrinsik-integratif.

\section{g. Kategori Motivasi Intrinsik-Instrumental}

Gabungan dua kategori kedua yang ditemukan pada penelitian ini adalah gabungan dari kategori intrinsik dan instrumental. Gabungan kedua kategori motivasi ini menunjukkan bahwa seseorang memiliki dorongan yang murni berasal dari dalam dirinya disertai dengan dorongan untuk memenuhi kebutuhan-kebutuhan praktisnya. Dalam hal mempelajari bahasa Inggris, gabungan kedua kategori motivasi ini menujukkan bahwa seseorang memiliki dorongan untuk yang berasal dari dirinya sendiri untuk memahami bahasa Inggris disertai dengan keinginan orang tersebut untuk dapat memperoleh pekerjaan yang lebih baik, mendapatkan tambahan pendapatan, dan atau untuk lulus dalam ujian melalui pemahaman bahasa Inggris tersebut. Jumlah responden yang memiliki gabungan dari motivasi intrinsik dan instrumental dalam mempelajari bahasa Inggris adalah 24 orang atau sebanyak $48 \%$ dari seluruh jumlah responden. Jumlah ini merupakan jumlah yang tertinggi 
yang ditemukan pada kategori-kategori motivasi yang lain. Rentangan nilai rata-rata kedua kategori motivasi tersebut terinterpretasikan tinggi, yaitu kategori motivasi intrinsik dengan rentangan nilai rata-rata $3,80-4,20$ dan kategori motivasi instrumental dengan rentangan nilai 4,20-4,60. Dari perhitungan nilai rata-rata kedua kategori motivasi tersebut diketahui kategori motivasi instrumental lebih tinggi muncul dalam diri kelompok responden tersebut. Sementara itu, ketiga kategori motivasi yang lain memiliki nilai rata-rata rendah, yaitu kategori motivasi ekstrinsik dengan rentangan nilai rata-rata 2,00-2,20; kategori motivasi integratif dengan rentangan nilai rata-rata 1,20 dan 2,00; dan kategori amotivasi dengan nilai rata-rata 1,00 .

Perbandingan rentangan nilai rata-rata setiap kategori motivasi pada kedua puluh empat orang responden tersebut dapat dilihat pada diagram 7 , yaitu yaitu kategori motivasi intrinsik memiliki rata-rata 4,13; kategori motivasi ekstrinsik memiliki rata-rata 2,03; kategori motivasi integratif memiliki rata-rata 1,32; kategori motivasi instrumental memiliki rata-rata 4,50; dan kategori amotivasi memiliki ratarata 1,00 . Dengan demikian dapat dinyatakan bahwa kategori motivasi yang dimiliki oleh kelima responden tersebut dalam mempelajari bahasa Inggris yang dominan adalah motivasi intrinsik-instrumental.

\section{h. Kategori Motivasi Ekstrinsik-Instrumental}

Gabungan dua kategori ketiga yang ditemukan dalam penelitian ini adalah gabungan kategori motivasi ekstrinsik dan instrumental. Gabungan kategori motivasi tersebut menujukkan bahwa seseorang memiliki dorongan untuk melakukan sesuatu yang berasal dari luar dirinya disertai dengan dorongan untuk memenuhi kebutuhan praktisnya. Dalam kaitannya dengan motivasi mempelajari bahasa Inggris, gabungan kedua motivasi ini menunjukkan bahwa seseorang mempelajari bahasa Inggris untuk memenuhi kebutuhan praktisnyas seperti memperoleh pekerjaan yang lebih baik, mendapatkan tambahan pendapatan, dan atau untuk lulus dalam ujian dengan dorongan yang berasal dari luar dirinya, seperti orang tua atau lingkungannya. Jumlah responden yang memiliki gabungan kedua kategori motivasi tersebut dalam mempelajari bahasa Inggris adalah 8 orang atau sebanyak $16 \%$ dari seluruh responden dalam penelitian ini.

Rentangan nilai rata-rata kedua kategori motivasi tersebut terinterpretasikan tinggi, yaitu kategori motivasi ekstrinsik dengan rentangan nilai rata-rata 4,00-4,20 dan kategori motivasi instrumental dengan rentangan nilai 4,60-5,00. Dari perhitungan nilai rata-rata kedua kategori motivasi tersebut diketahui kategori motivasi instrumental lebih tinggi muncul dalam diri kedelapan responden tersebut. Sementara itu, ketiga kategori motivasi yang lain memiliki nilai rata-rata rendah, yaitu kategori motivasi intrinsik dengan rentangan nilai rata-rata $1,00-1,80$; kategori motivasi integratif dengan rentangan nilai rata-rata 1,40 dan 1,80; dan kategori amotivasi dengan nilai rata-rata 1,00 .

Perbandingan rentangan nilai rata-rata setiap kategori motivasi pada kedelapan orang responden tersebut dapat dilihat pada diagram 8 , yaitu yaitu kategori motivasi intrinsik memiliki rata-rata 2,08; kategori motivasi ekstrinsik memiliki rata-rata 4,18; kategori motivasi integratif memiliki rata-rata 1,40; kategori motivasi instrumental memiliki rata-rata 4,53; dan kategori amotivasi memiliki rata-rata 1,00. Dengan demikian dapat dinyatakan bahwa kategori motivasi yang dimiliki oleh kelima 
responden tersebut dalam mempelajari bahasa Inggris yang dominan adalah motivasi ekstrinsik-instrumental.

\section{Stimulan yang Tepat berdasarkan Kategori Motivasi yang dimiliki oleh Tenaga Kerja RSD Mangusada dalam Mempelajari Bahasa Inggris}

Berdasarkan hasil analasis data, diketahui bahwa gabungan kategori motivasi intrinsik dan instrumental adalah kategori motivasi yang paling banyak ditemukan dengan jumlah $48 \%$ atau 24 orang dari seluruh responden. Data tertinggi kedua ditunjukkan oleh responden yang memiliki gabungan antara motivasi ekstrinsik dan instrumental, yakni sebesar $16 \%$ atau 8 orang dari seluruh responden. Pada kedua data tersebut, nilai rata-rata kategori motivasi instrumental lebih tingi dari nilai ratarata kategori motivasi intrinsik maupun ekstrinsiknya. Sementara itu, kategori motivasi yang paling sedikit yang ditemukan dalam penelitian ini adalah kategori motivasi instrumental dengan jumlah 1 orang atau 4\% dari seluruh responden. Data ini menunjukkan bahwa kecenderungan seseorang untuk mempelajari bahasa Inggris sangat dipengaruhi oleh keinginan untuk memenuhi kepentingan pragmatis, seperti memperoleh pekerjaan yang lebih baik, mendapatkan tambahan pendapatan, dan atau untuk lulus dalam ujian. Namun, dorongan untuk memenuhi kepentingan pragmatis tersebut tidak murni muncul secara tunggal dalam diri seseorang dalam mempelajari bahasa Inggris. Dorongan tersebut juga mempengaruhi dan/atau dipengaruhi oleh kategori motivasi yang lain seperti motivasai intrinsik dan ekstrinsik.

Sebagian besar tenaga kerja RSD Mangusada memiliki motivasi intrinsik instrumental dalam mempelajari bahasa Inggris. Seseorang dengan motivasi intrinsic yang kuat cenderung untuk bertahan dalam proses pemebelajaran bahasa dan akan lebih aktif dalam mencari solusi dari permasalah tersebut. Ini disebabkan oleh dorongan yang dimiliki dalam mempelajari bahasa tersebut muncul murni dari dalam dirinya tanpa ada paksakan dari orang lain.

Jika motivasi intrisnik ini didukung oleh motivasi instrumental, dorongan untuk mempelajari bahasa Inggris akan lebih kuat. Hal ini akan berdampak positif pada capaian hasil belajarnya. Meskipun dorongan dari dalam dirinya juga dipengaruhi oleh keinginannya untuk memenuhi kepentingan pragmatisnya, namun dorongan dari dalam diri tersebut cukup untuk membuatnya secara sukarela mempelajari bahasa Inggris untuk peningkatan kompetensi dirinya. Dengan motivasi yang sudah berasal dari diri peserta didik sendiri, tenaga pengajar dapat menerapkan berbagai macam strategi dalam pelaksanaan proses pembelajaran. Hal ini akan lebih memudahkan tenaga pengajar dalam mempersiapkan kegiatan belajar.

Kategori motivasi terbanyak kedua yang dimiliki oleh tenaga kerja RSD Magusada dalam mempelajari bahasa Inggris adalah motivasi ekstrinsik instrumental. Motivasi ekstrinsik mengindikasikan bahwa dorongan seseorang dalam mempelajarai bahasa Inggris sangat bergantung pada kondisi di luar dirinya. Sehingga stimulan yang berasal dari luar akan sangat mempengaruhi semangat belajarnya. Mengingat bahwa hasil analysis data menunjukkan bahawa cukup banyak tenaga kerja RSD Mangusada yang memiliki motivasi ekstrinsik, maka stimulan tersebut harus diperhatikan. Motivasi kedua terbanya ini juga dipengaruhi oleh motivasi instrumental yang sepenuhnya bertujuan untuk memenuhi kepentingan pragmatis. Maka stimulan yang diberikan juga harus 
mempertimbangkan nilai pragmatis yang dapat diperoleh ketika tenaga kerja RSD Mangusada mengikuti pelatihan bahasa Inggris.

Satu hal lain yang perlu diperhatikan adalah kedua kategori motivasi terbanyak yang ditemukan pada tenaga kerja RSD Mangusada dalam mempelajari bahasa Inggris adalah adanya unsur motivasi instrumental. Dengan demikian, jika RSD Mangusada hendak mengadakan pelatihan bahasa Inggris untuk meningkatkan kompetensi SDM-nya dalam upaya peningkatan mutu pelayanan, pertimbangan stimulan yang memberi manfaat pragmatis bagi tenaga kerja RSD Mangusada layak untuk dipertimbangkan. Kepentingan pragmatis tersebut adalah keinginan untuk mendapatkan karir yang lebih baik dan/atau mendapatkan penghasilan yang lebih besar. Dengan demikian, stimulant berupa promosi karir bagi tenaga kerja yang berhasil meningkatkan kompetensi dalam berbahasa Inggris merupakan sebuah stimulant yang baik. Selain itu, pemberian insentif bagi tenaga kerja yang berhasil meningkatkan kompetensi berbahasa Inggrisnya juga merupakan stimulant lain yang dapat diambil oleh pihak manajemen RSD Mangusada.

\section{PENUTUP}

Kategori motivasi dalam mempelajari bahasa Inggris yang dimiliki oleh tenaga kerja RSD Mangusada Badung adalah lima kategori motivasi tunggal dominan dan tiga kategori motivasi gabungan dominan. Lima kategori motivasi tunggal dominan tersebut adalah kategori motivasi intrinsik dominan, kategori motivasi ekstrinsik dominan, kategori motivasi integratif dominan, kategori motivasi instrumental dominan, dan kategori amotivasi dominan. Tiga kategori motivasi gabungan dominan yang ditemukan dalam penelitian ini adalah kategori motivasi intrinsikintegratif dominan, kategori motivasi intrinsik-instrumental dominan, dan kategori motivasi ekstrinsik-instrumental dominan. Kategori motivasi yang paling banyak ditemukan adalah kategori motivasi intrinsik-instrumental dominan sebanyak $48 \%$ dari seluruh responden dalam penelitian ini dan dilanjutkan dengan kategori motivasi ekstrinsik-instrumental sebanyak 16\% dari seluruh responden. Dua kategori motivasi memiliki jumlah yang sama, yaitu kategori motivasi ekstrinsik dan ekstrinsik-integratif dengan jumlah responden masing-masing sebesar $10 \%$ dari seluruh jumlah responden. Motivasi intrinsik dominan memiliki jumlah responden sebesar $6 \%$ dari seluruh jumlah responden. Kategori motivasi integratif dominan dan amotivasi dominan memiliki jumlah responden yang sama, yaitu sebesar $4 \%$ dari seluruh jumlah responden. Kategori motivasi dengan jumlah responden terkecil adalah kategori motivasi instrumental dominan, yaitu sebesar $2 \%$ dari seluruh jumlah responden.

Sesuai dengan tujuan RSD Mangusada dalam meningkatkan kompetensi berbahasa Inggris seluruh tenaga kerja dalam upaya meningkatkan mutu pelayanan melalui pelatihan bahasa Inggris, maka penentuan stimulan yang tepat untuk memeprtahankan dan meningkatkan motivasi dalam mempelajari bahasa Inggris perlu dilakukan. Hal ini bertujuan agar kegiatan pelatihan bahasa Inggris yang direncanakan dapat mencapai hasil yang optimal. Berdasarkan hasil analisis kategori motivasi yang dimiliki oleh tenaga kerja RSD Mangusada dalam mempelajari bahasa Inggris, maka stimulan yang bersifat pragmatis perlu diberikan. Stimulan tersebut dapat berupa promosi karir ataupun pemberian insentif bagi tenaga kerja yang mampu meningkatkan kompetensi berbahasa Inggrisnya. 


\section{DAFTAR PUSTAKA}

Al-Ta'ani, M. H. (2018). Integrative and Instrumental Motivations for Learning English as a University Requirement among Undergraduate Students at AlJazeera University/Dubai. International Journal of Learning and Development, 8(4), 89-105. https://doi.org/10.5296/ijld.v8i4.13940

Aydoğan, H. (2016). Intrinsic and Extrinsic Motivation for English Learning Scale (IEM-ELS): A Psycholinguistics Study of Reliability and Validity. Celal Bayar Üniversitesi Sosyal Bilimler Dergisi, 14(3), 56-66. https://doi.org/10.18026/cbusos.66920

Baron, R. A. (1996). Psychology. New Delhi: Prentice-Hall of India.

Delgado, D. A. G. (2016). Survey Study of Integrative and Instrumental Motivation in English Language Learning of First-year Students at Naresuan University International College (NUIC), Thailand. 6th International Conference on Language, Education, and Innovation, 6-16. Retrieved from https://icsai.org/procarch/6iclei/6iclei-003.html

Gardner, R. C. (1985). Social Psychology and Second Language Learning: The Role of Attitudes and Motivation. London: Edward Arnold.

Horwitz, E. K. (2002). Psychology for Language Teachers: A Social Constructivist Approach. English for Specific Purposes, 21(2), 203-206. https://doi.org/10.1016/s0889-4906(01)00011-4

Johnstone, K. (1999). Language Learning. London: Routledge.

Kamaruddin, R., Sha'ri, S. N., Ghazali, A. H. A., \& Hamdan, R. (2017). Intrinsic and Extrinsic Motivation as Extralinguistics Factors in Second Language Learning Among Foreign Students in Five Universities of Malaysia. Journal of US-China Public Administration, 14(1), 26-37. https://doi.org/10.17265/15486591/2017.01.003

Long, C., Ming, Z., \& Chen, L. (2013). The Study of Student Motivation on English Learning in Junior Middle School -- A Case Study of No.5 Middle School in Gejiu. English Language Teaching, 6(9), 136-145. https://doi.org/10.5539/elt.v6n9p136

Mahadi, T. S. T., \& Jafari, S. M. (2012). Motivation, Its Types, and Its Impacts in Language Learning. International Journal of Business and Social Science, 3(24), 230235. Retrieved from http://ijbssnet.com/journals/ Vol_3_No_24_Special_Issue_December_2012/24.pdf

Pakdel, B. (2013). The Historical Context of Motivation and Analysis Theories Individual Motivation. International Joumal of Humanities and Social Science, 3(18), 240-247. Retrieved from http://ijhssnet.com/journals/ Vol_3_No_18_October_2013/23.pdf

Rashid, S., \& Akram, R. (2019). Relationship between the Levels of Motivation and Learning Strategies of Prospective Teachers at Higher Education Level. Bulletin of Education and Research, 41(1), 57-66. Retrieved from http://pu.edu.pk/images/journal/ier/PDF-FILES/5_41_1_19.pdf

Ryan, R. M., \& Deci, E. L. (2000). Intrinsic and Extrinsic Motivations: Classic Definitions and New Directions. Contemporary Educational Psychology, 25(1), 5467. https://doi.org/10.1006/ceps.1999.1020

Shaikholeslami, R., \& Khayyer, M. (2006). Intrinsic Motivation, Extrinsic Motivation, and Learning English as a Foreign Language. Psychological Reports, 99(7), 813-818. https://doi.org/10.2466/PR0.99.7.813-818 
